\title{
Home visits of the nurse and its relationship with hospitalization by diseases sensitive to primary health care
}

\author{
Visitas domiciliares do enfermeiro e sua relação com as internações por doenças sensíveis \\ à atenção básica
}

Visitas domiciliares del enfermero y su relación con las hospitalizaciones por enfermedades sensibles a la atención primária

\author{
Mayra Romélia Leite Garcia ${ }^{1}$ \\ Daniel Souza Sacramento ${ }^{2}$ \\ Hadelândia Milon de Oliveira ${ }^{1}$ (1) \\ Maria Jacirema Ferreira Gonçalves ${ }^{1,3}$ (1) \\ 1. Universidade Federal do Amazonas. \\ Manaus, AM, Brasil. \\ 2. Prefeitura Municipal de Manaus, Secretaria \\ Municipal de Saúde de Manaus. Manaus, \\ AM, Brasil. \\ 3. Instituto Leônidas e Maria Deane, Fundação \\ Oswaldo Cruz. Manaus, AM, Brasil.
}

Corresponding author:

Hadelândia Milon de Oliveira.

E-mail: hmilon@ufam.edu.br

Submitted on 09/22/2018.

Accepted on $12 / 17 / 2018$.

DOI: 10.1590/2177-9465-EAN-2018-0285

\begin{abstract}
Objective: To identify if nurses' home visits recorded by the family health strategy are proportional to the registered population and the population covered by the family health team, and its relationship with the rate of hospitalization for conditions sensitive to primary health care. Method: Secondary data were gathered from the Information Systems of Primary Care and Hospitalization regarding potential population coverage, number of visits done, hospitalizations for diseases sensitive to primary health care. An exploratory analysis was performed with data grouping for triennium (2010-2012 and 2013-2015) and assignment of scores for each variable, creating the classification strata in: low, medium and high. Results: It was identified that the number of registered home visits does not meet the estimated population coverage as well as does not impact on the admissions sensitive to primary health care. Conclusion and implications for practice: Even with high coverage of the family health strategy, home visits are not the main focus of nurses yet. Home visits should be used as a tool for disease prevention and health promotion, which may explain the non-reduction of hospitalizations sensitive to primary health care.
\end{abstract}

Keywords: Family Health Strategy; Home Calls; Primary Health Care.

\section{Resumo}

Objetivo: Identificar se as visitas domiciliares registradas pela estratégia saúde da família são proporcionais à população registrada e à população coberta pela estratégia, e sua relação com a taxa de internação por condições sensíveis a atenção básica. Método: Foram coletados dados secundários do Sistema de Informação da Atenção Básica e Sistema de Informações Hospitalares referentes a: cobertura populacional potencial, número de visitas realizadas, internações por doenças sensíveis a atenção básica. Foi realizada análise exploratória com agrupamento dos dados por triênio (2010-2012 e 2013-2015) e atribuição de escores para cada variável, permitindo estabelecer a classificação a baixa, média e alta. Resultados: Identificou-se que a quantidade de visitas domiciliares registradas não atende a cobertura populacional estimada, assim como não impacta nas internações sensíveis à atenção básica. Conclusão e implicações para a prática: Mesmo com elevada cobertura da estratégia saúde da família, as visitas domiciliares ainda não são o principal foco dos enfermeiros. As visitas domiciliares deveriam ser utilizadas como ferramenta de prevenção de doenças e promoção da saúde, o que talvez explique a não redução das internações sensiveis à atenção básica.

Palavras-chave: Estratégia Saúde da Família; Visita Domiciliar; Atenção Primária à Saúde.

\section{Resumen}

Objetivo: Identificar si las visitas domiciliarias registradas en la Estrategia Salud de la Familia son proporcionales a la población registrada y la población cubierta por la estrategia, y su relación con la tasa de internación por condiciones sensibles a la atención básica. Método: Se recogieron datos secundarios del Sistema de Información de la Atención Básica y Sistemas de Información Hospitalaria con respecto a: cobertura poblacional potencial, número de visitas realizadas, internaciones por enfermedades sensibles a la atención básica. Se ha llevado a cabo un análisis exploratorio con agrupación de los datos por trienio (2010-12 y 2013-15) y asignación de escores para cada variable, permitiendo establecer la clasificación en baja, media y alta. Resultados: Se identificó que la cantidad de visitas domiciliarias registradas no atiende la cobertura poblacional estimada así como no impacta en las internaciones sensibles a la atención básica. Conclusión e implicaciones para la práctica: A pesar de la elevada cobertura de la estrategia salud de la familia, las visitas domiciliarias aún no son el principal foco de los enfermeros. Las visitas domiciliarias deberían ser utilizadas como herramienta de prevención de enfermedades y promoción de la salud, lo que quizá explique la no reducción de las internaciones sensibles a la atención básica.

Palabras clave: Estrategia de Salud Familiar; Visita domiciliaria; Atención Primaria de Salud. 


\section{INTRODUCTION}

Regulated by the Primary Health Care National Policy (named in Brazil as PNAB - Política Nacional de Atenção Básica) in Brazil, the primary health care (PHC) determines the family as the main object of care, which by means of the Family Health Strategy (FHS) establishes the link between the population and the health system. Its guidelines are: have territory ascribed, universal access, linking of people, families and groups to professionals or health teams, with the purpose of being a reference for its care, enabling link and confidence between the user and the health professional. ${ }^{1,2}$

Among the tasks of the FHS team, we highlight the home visits, programmed or turned towards the attending to spontaneous demands, according to epidemiological criteria and risk stratification of the population attended. ${ }^{3}$ These in turn, enable the nurses to know the social context and identify the families' health needs attended by these professionals, enabling a greater closeness with the health-disease process determinants, supporting actions of intervention aiming at preventing diseases and promoting the community health.

Although the home visit practice may not be conceived as the single element that influences the hospitalizations for sensitive conditions to $\mathrm{PHC}$, it can be regarded as a proxy for health care, especially with regard to the prevention and health promotion, as well as it can be a performance indicator for the FHS in the territory. ${ }^{4}$ Moreover, it should consider that the quantitative of visits does not express its quality and even can suffer interference from the population coverage, which in turn, can directly influence the number of visits. ${ }^{5}$ This number can also be influenced by the population's health needs, which does not allow the proportional uniformity between the number of visits and the number of families registered.

The rate of hospitalization for sensitive conditions to $\mathrm{PHC}$ is an indirect performance indicator for the family health team's, ${ }^{6,7}$ which have conditions to act preventively against chronic conditions that represent the main causes of avoidable hospitalizations; however, specific studies on home visit by nurses are not detected and neither with respect to the hospitalizations for primary care sensitive conditions.

This article aims to identify if the home visits registered by the FHS are proportional to the population registered and to the population covered by the FHS, and identify its relationship with the hospitalizations for sensitive conditions to PHC.

\section{METHODS}

Epidemiology, ecological, qualitative study using secondary data from the SUS Department of Information Technology (www.datasus.gov.br. Access in 06/28/2016), through the Basic Health Care Information System (SIAB, Sistema de Informação da Atenção Básica) and Hospital Information Systems (SIH, Sistema de Informação Hospitalar).
The data from this study relate to the municipalities of the State of Amazonas. The Amazonas, according to the Brazilian Institute of Geography and Statistics ${ }^{a}$, is the largest state in territorial scope of the Federation with 1,559,146.2 $\mathrm{km}^{2}$. In 2017 , its population estimated was $4,080,611$ inhabitants, with demographic density of 2.23 inhab. $/ \mathrm{km}^{2}$. These geographical characteristics make it unfavorable for the population to access to health services which added to socioeconomic conditions, leave it vulnerable to several health conditions, ${ }^{5}$ especially those in which the $A B$ has direct performance.

For the annual data collection regarding nurse visits by the number of families registered at the FHS and analysis of potential population coverage for Amazonas municipalities in the period from 2010 to 2015 , the following variables were collected at the SIAB: total population, assistance limit, FHS accredited by Ministry of Health, FHS registered at the SIAB, FHS implemented, estimated covered population, proportion of the potential population coverage, number of registered homes that received visits each month of years selected.

Data regarding the number of hospitalization for primary care sensitive conditions ${ }^{8,9}$ were collected at the SIH (www.datasus. gov.br. Access in 07/28/2016) based on the morbidity list of the International Statistical Classification of Diseases and Related Health Problems $-10^{\text {th }}$ revision. ${ }^{10}$ Number of hospitalizations data were collected for: Asthma (J45), Heart failure (I50), Pneumonia (J12 to J18), Diarrhea and gastroenteritis of presumed infectious origin (A09), and, the rate of hospitalization, later on, calculated for this group of diseases, using as the denominator the total population estimated for each municipality, as the calculation below:

$\begin{gathered}\text { Rate of } \\ \text { Hospitalization }\end{gathered}=\frac{\begin{array}{c}\text { (Number of } \\ \text { hospitalizations from } \\ \text { selected causes) }\end{array}}{\begin{array}{c}\text { (Estimated population in } \\ \text { the period evaluated) }\end{array}} \times 100,000$

For analysis of potential population coverage, the potential population coverage calculation was made, according to the formula used by the Health Ministry: ${ }^{11}$

$\begin{gathered}\text { Potential } \\ \begin{array}{c}\text { populacion } \\ \text { coverage }\end{array}\end{gathered}=\frac{3,450)}{\begin{array}{c}\text { (Number of teams } x \\ \text { residents) }\end{array}} \times 100,000$

For data available each month we chose the month of July as the representative of the referred year, accompanying the Brazilian Institute of Geography and Statistics (IBGE) recommendation in which, the reference month adopted is the one that preceding the month of realization for the new research. ${ }^{12}$ 
In order to analyze the number of visits carried out by nurses it was considered one visit of the nurse for each month every year, as number desirable, for each family registered by number of teams in each municipality. Then it was calculated the splitter ratio of homes visits, dividing the number of visits carried out by the number desirable of visits, as envisioned by Regulation no. 2.436, from September 21 of 2017 . $^{1}$

The data analysis occurred in two phases: exploratory phase and grouping phase.

In the exploratory phase, the annual data were estimated by frequency and percentage per municipality, exploring their differences and assessing their distribution, mean and standard deviation. Analyzing data variation in the years, it was decided to group by the average of annual data for trienniums: 2010 to 2012 and 2013 to 2015.

In the second step of the data analysis, there was assessment of the average data of all variables, with attribution of scores and classifications, as detailed below:

- Potential population coverage according to the following cut off points: high coverage (higher than $70 \%$ ), mean coverage (between $50 \%$ and $70 \%$ ) and low coverage (less than $50 \%$ ), according to values adopted in other studies; 5,13

- Home visits carried out by the FHS nurses, with the following scores attributed: score 1 (one) whose value was within the expected range, that is, at least one home visit by the nurse per month during the year totaling twelve visits per year, for registered family: and score 0 (zero) for values below this range.

- Rate of hospitalization, stratified into tertiles, attributing specific scores to determine the classification of the rate of hospitalization caused by sensitive diseases, as shown in the chart below:

At the end of the period, tables have been formulated by crossing the scores and classifications by municipalities in accordance with the trienniums analyzed; in order to identify discrepancies and similarities of classification of hospitalization, regarding the home visit by the nurse.

\section{RESULTS}

During the period from 2010 to 2015 1,812,208 home visits were registered by nurses in the Amazonas. This corresponds on average to 1 (one) visit per family registered in the FHS per year. This number was similar when we observe this study into two separate sets of years, 2010-2012 and 2013-2015.

The average coverage of the FHS was classified as high for $47.5 \%$ municipalities in the first triennium, and $41.9 \%$ of municipalities in the second triennium. Although the quantity of cities in the high classification has decreased, we observe a movement of municipalities from low and medium classification to medium or high. In this item, it was not possible to classify São Gabriel da Cachoeira, due to a lack of data (Table 1).

Regarding the ratio between the number of visits carried out and number of desirable visits in the municipalities it was observed that only approximately $30 \%$ of municipalities obtained the ratio 1 (one) or more visits, in both trienniums analyzed. The following municipalities showed improvement in the ratio of visits of the first triennium to the second triennium, Barreirinha, Manaus and Maraã; in contrast, the municipalities that showed decline in ratio of visits were as follows: Fonte Boa, Humaitá, Parintins and Urucurituba (Table 1).

By observing the rates of hospitalization for sensitive diseases to primary health care, it was possible to see from the division into tertiles, that 21 municipalities had high rate of hospitalizations during the first triennium reducing, for medium and low classification during the second triennium, being 8 municipalities: Anamã, Codajás, Itapiranga, Manicoré, São Gabriel da Cachoeira, São Sebastião do Uatumã, Silves and Urucará. However, in other nine municipalities, marked in bold font in the Table 1, there was an increase in the rate of hospitalizations, as follows: Borba, Coari, Fonte Boa, Iranduba, Itamarati, Juruá, Manacapuru, Maués and Novo Airão.

It can be observed a decrease in the average rate of hospitalization for sensitive diseases to primary health care in the Amazonas, from the first triennium to the second triennium analyzed, passing from 1,208.3 hospitalizations/100 thousand inhabitants in the first triennium to 843.0 hospitalizations/100 thousand inhabitants in the second triennium despite the ratio of home visits remained stable during the period.

Chart 1. Distribution of tertiles, score and classification of the rate of hospitalization caused by sensitive conditions per 100 thousand inhabitants in the trienniums 2010 to 2012 and 2013 to 2015, Amazonas.

\begin{tabular}{|lcccc|}
\hline \multirow{2}{*}{ Tertil } & Rate of hospitalization caused by sensitive conditions per $\mathbf{1 0 0}$ thousand inhabitants & Score & Classification \\
& $\mathbf{2 0 1 0 - 2 0 1 2}$ & $\mathbf{2 0 1 3} \mathbf{2 0 1 5}$ & 1 & Low \\
\hline $1^{\text {st }}$ Tertil & $\leq 872$ & $\leq 465$ & 2 & Medium \\
$2^{\text {nd }}$ Tertil & 873 to 1,376 & 466 to 1,063 & 3 & High \\
$3^{\text {rd }}$ Tertil & $\geq 1,377$ & $\geq 1,064$ & 3 \\
\hline
\end{tabular}

Note: The following causes of hospitalization were selected: Asthma (J45), Heart failure (I50), Pneumonia (J12 to J18), Diarrhea and gastroenteritis of presumed infectious origin (A09). 
Table 1. Total population coverage and ratio of home visits (HV) Amazonas (2010-2015).

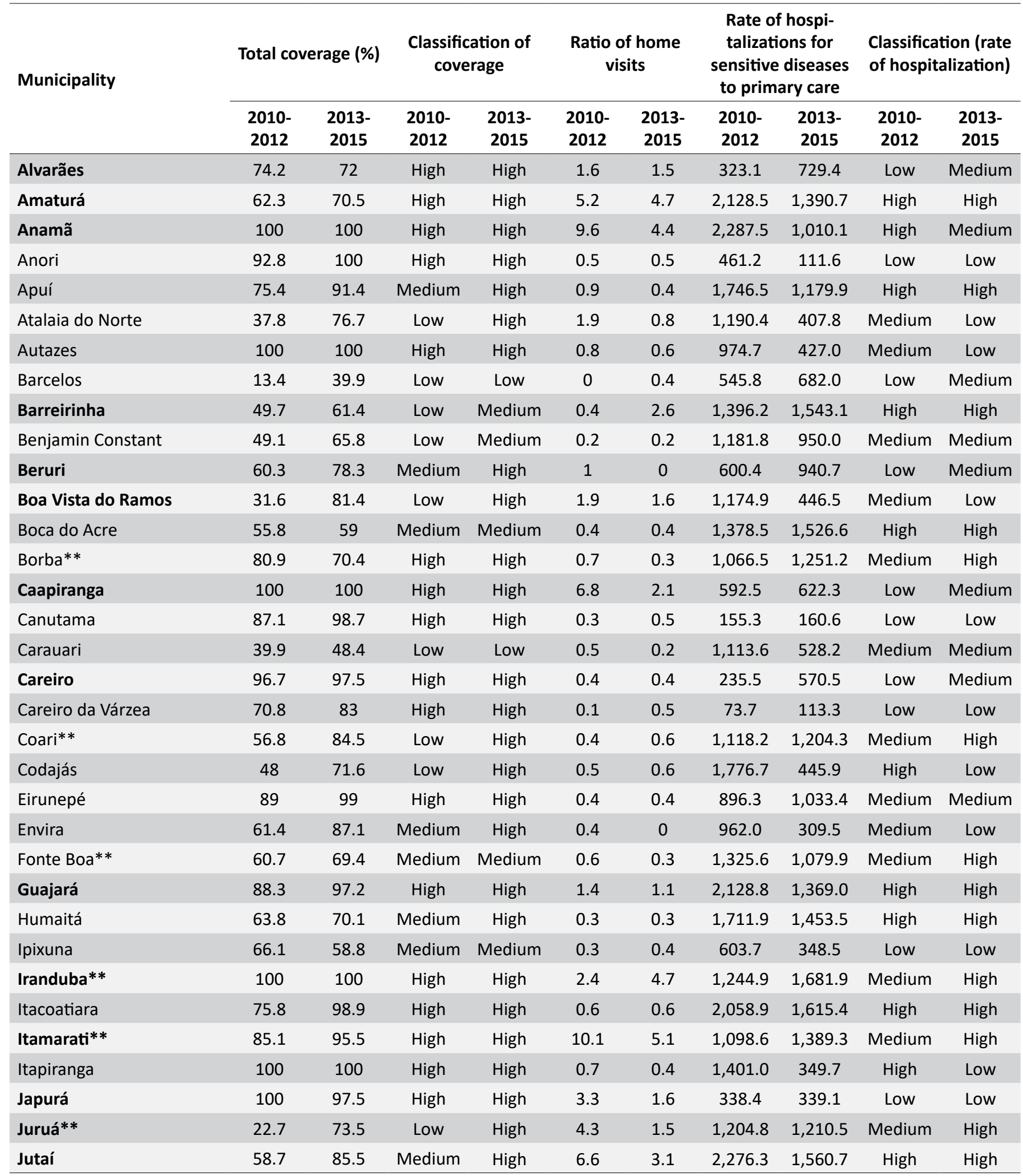




\begin{tabular}{|c|c|c|c|c|c|c|c|c|c|c|}
\hline \multirow[t]{2}{*}{ Municipality } & \multicolumn{2}{|c|}{ Total coverage (\%) } & \multicolumn{2}{|c|}{$\begin{array}{c}\text { Classification of } \\
\text { coverage }\end{array}$} & \multicolumn{2}{|c|}{$\begin{array}{l}\text { Ratio of home } \\
\text { visits }\end{array}$} & \multicolumn{2}{|c|}{$\begin{array}{l}\text { Rate of hospi- } \\
\text { talizations for } \\
\text { sensitive diseases } \\
\text { to primary care }\end{array}$} & \multicolumn{2}{|c|}{$\begin{array}{l}\text { Classification (rate } \\
\text { of hospitalization) }\end{array}$} \\
\hline & $\begin{array}{l}2010- \\
2012\end{array}$ & $\begin{array}{l}2013- \\
2015\end{array}$ & $\begin{array}{l}2010- \\
2012\end{array}$ & $\begin{array}{l}2013- \\
2015\end{array}$ & $\begin{array}{l}2010- \\
2012\end{array}$ & $\begin{array}{l}2013- \\
2015\end{array}$ & $\begin{array}{l}2010- \\
2012\end{array}$ & $\begin{array}{l}2013- \\
2015\end{array}$ & $\begin{array}{l}2010- \\
2012\end{array}$ & $\begin{array}{l}2013- \\
2015\end{array}$ \\
\hline Lábrea & 65.6 & 70.7 & Medium & High & 0.6 & 0.7 & 477.0 & 294.6 & Low & Low \\
\hline Manaquiri & 46.3 & 75.6 & Low & High & 0.8 & 1.9 & 997.1 & 505.9 & Medium & Medium \\
\hline Manaus & 29.4 & 33.2 & Low & Low & 0.3 & 0.3 & $1,842.0$ & $1,613.4$ & High & High \\
\hline Manicoré & 56.1 & 71.3 & Medium & High & 0.4 & 0.5 & $2,970.7$ & 743.4 & High & Medium \\
\hline Maraã & 19.4 & 58.8 & Low & Medium & 3.2 & 1.2 & $4,697.6$ & $1,546.3$ & High & High \\
\hline Novo Airão** & 60.7 & 85.3 & Medium & High & 0.8 & 0.2 & 860.5 & 505.9 & Low & High \\
\hline Novo Aripuanã & 55.4 & 72.8 & Medium & High & 1.7 & 1.1 & $2,883.3$ & $2,547.9$ & High & High \\
\hline Parintins & 74 & 74.2 & High & High & 0.5 & 0.4 & $1,372.7$ & 880.4 & Medium & Medium \\
\hline Pauini & 31.3 & 56.5 & Low & Medium & 3.9 & 4.9 & 778.2 & 747.5 & Low & Medium \\
\hline Presidente Figueiredo & 100 & 100 & High & High & 0.4 & 0.5 & $2,020.2$ & $1,658.4$ & High & High \\
\hline Rio Preto da Eva & 100 & 100 & High & High & 1.5 & 0.5 & $1,309.9$ & 960.8 & Medium & Medium \\
\hline Santa Isabel do Rio Negro & 43.5 & 59.6 & Low & Medium & 1.9 & 1.1 & 566.2 & 87.6 & Low & Low \\
\hline Santo Antônio do Içá & 30.9 & 85.1 & Low & High & 1.2 & 1.6 & 506.3 & 837.3 & Low & Medium \\
\hline Tapauá & 56.2 & 71.8 & Medium & High & 5.1 & 1.6 & $1,151.1$ & 405.1 & Medium & Low \\
\hline Tefé & 100 & 98.8 & High & High & 0.2 & 0.2 & $1,584.3$ & $1,465.0$ & High & High \\
\hline Tonantins & 68.1 & 79.2 & Medium & High & 4.8 & 3.7 & 314.0 & 87.3 & Low & Low \\
\hline Uarini & 100 & 79.8 & High & High & 2 & 0.5 & 291.3 & 84.9 & Low & Low \\
\hline Urucará & 95.4 & 100 & High & High & 0.5 & 0.5 & $1,447.3$ & 556.0 & High & Medium \\
\hline Urucurituba & 100 & 100 & High & High & 1.1 & 1.2 & 284.8 & 247.4 & Low & Low \\
\hline \multicolumn{11}{|c|}{ Source: DATASUS - SIAB (28 June 2016). } \\
\hline \multicolumn{11}{|c|}{$\begin{array}{l}\text { Notes: The following causes of hospitalization were selected: Asthma (J45), Heart failure (I50), Pneumonia (J12 to J18), Diarrhea and gastroenteritis of presumed } \\
\text { infectious origin (A09). Ratio of home visits (HV) = (HV carried out/number of desirable HV). Number of desirable home visits = one monthly nurse visit in each } \\
\text { registered family, by the number of teams from each municipality. }\end{array}$} \\
\hline
\end{tabular}


We notice in Figure 1 that in the first triennium the group of municipalities with low rate of hospitalization showed the highest average ratio of home visit compared to medium and high rate of hospitalization, however, this pattern is not observed during the second triennium in which the average ratio of home visit are almost equal in these groups. In addition, we can observe municipalities with high ratio of hospitalization in all groups of rate of hospitalization, as well as great variability between the groups in the two triennium.

\section{DISCUSSION}

With this research, it has been possible to obtain an overview about the coverage of the FHS in the State of Amazonas, as well as the occurrence of the home visits carried out by the nurses and their relation to the rate of hospitalization for sensitive diseases to PHC in the period from 2010 to 2015.

It showed the lack of relationship between the population coverage by the FHS and the ratio of home visits. This can indicate that the home visits do not occur as recommended by the PNAB. ${ }^{1}$ We notice that, in the first triennium, despite the high population coverage by the FHS in most municipalities, few of these have reached the score one (1) for the minimum desirable quantity of home visits. It also noted an increase in the number of municipalities with high coverage by the FHS in the second triennium in contrast, however there was a decrease in the number of municipalities with ratio of home visits equal or greater than one (1). With this, it appears that the coverage by the FHS does not ensure the minimum quantity of home visits. The absence of the monthly home visit by the nurse can lead important needs not identified and thus represent a problem to the health care of these persons. However studies show that besides extending the coverage, it is common to occur the prioritization of the services, such as home visits in the situation of vulnerability, or that nurses carry out visits only when requested..$^{14,15}$
However, it has to be considered that the State of Amazonas has geographical characteristics unfavorable to the easier access to health care services, not providing any guarantee that calculated coverage is, in fact, to be effected, taking into account the population, which live in remote areas or those, which access is difficult. ${ }^{5}$

Considering that the present research bases on secondary data, the actual number of visits is unknown, because there is a possibility of under-registration, especially when it decides to make a visit without any programing, due to the needs of the population. On the other hand, there is also the possibility of existing over-records, in other words, the visit is recorded, but is not carried out, either through reprograming, or on demand in the own health service. ${ }^{16}$ Despite these considerations, it is thought that the FHS teams have interests in achieving their goals, and the carrying out of home visit by the nurse is included, in this way, which indicates that the results found show that it falls well short of meeting the criteria for a visit each month for family registered.

It should also be pointed out that the research results are based on data on hospitalization and not on individuals, since the $\mathrm{SIH}$ unit record is the event. Thus, multiple hospitalizations for diseases sensitive to PHC from the same patient could not be identified and, in addition, the data refer only to hospitalizations made by SUS, limited to possibility of extrapolations. On the other hand, the rate of private health plan coverage in the Amazonas during this period was $13.2 \%$, considered low when compared to the rest of the country, and almost all the residents from the interior of the Amazonas use the public health system with rate of private health plan coverage of only $1.0 \%$ in the period (http://www.ans.gov.br/anstabnet. Access in May 01, 2018).

Another aspect that must be considered is that the present analysis did not enable identifying the origin of patients who were hospitalized for sensitive conditions, in order to know whether they had access or not to the FHS, since the geographical distances in the poles of health services in the municipalities in the interior of Amazonas leave many people without primary

Figure 1. Boxplot of the ratio of home visit and categories of rate of hospitalization for sensitive conditions to primary health care. A: Triennium 2010 - 2012 ; B: Triennium 2013 - 2015.
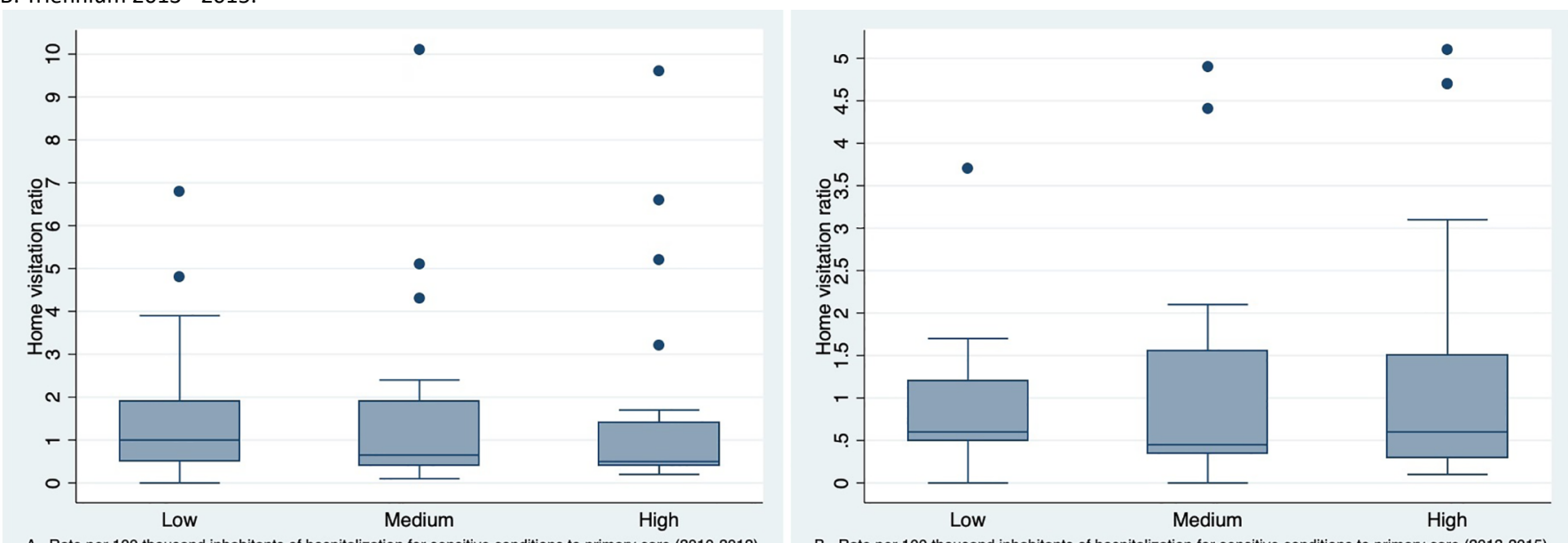

Escola AnNa Nery 23(2) 2019 
care generating the intensification of health problems for this population. ${ }^{5}$ It would cause increased demand for hospitalizations that, even being for conditions sensitive to primary care, it cannot be attributed to it, since the patients already arrive in severe situations, which requires hospital treatment.

The FHS should guarantee resolute care to the users' health problems, avoiding unnecessary hospitalizations, in this respect it is understood that the home visits would take the professional closer to the reality of the user, enabling the early identification of the users' health needs. Corroborating this fact, is considered that the carrying out of the home visits should be the least that should happen for the implementation of the definitive strategy, because it is an assumption of the FHS, as soft technology of interaction in the healthcare. ${ }^{17,18}$

The home visit as external activity of the health unit is considered the more developed activity by the health teams. According to data from the first cycle of the external evaluation of the Program for Access and Quality Improvement (PMAQ), $100 \%$ of the health teams evaluated in the Amazonas, reported that carried out home visit, but only $56.1 \%$ of them reported that carried out from an organized care agenda and only $13.3 \%$ use risk classification priorities protocol according to degree of risk and vulnerability. ${ }^{19}$

Thus, it is understood that the home visit by the nurse is carried out by means of spontaneous demand or according to "problematic" situations removing the preventive character of the visit, since most professionals face situations that extrapolate the basic attention level complexity and the team effort is low resolute. Despite this, the work method in the FHS must organized in an integrated approach, to establish a link between the professionals and users, by incorporating the different work processes, a practice that facilitates the interaction among the FHS professionals. ${ }^{18}$

In addition, studies report that there is a requirement by the municipal management to achieve productivity goals both for the carrying out of the home visit and for the other FHS activities. As such, the nurses face a dilemma, since, sometimes, they need to opt for carrying out a smaller number of home visits to accomplish other goals, fact that contributes to the nursing practice centered in the users' immediate demands. ${ }^{13,15,17}$

The home visit allows reflections on practice, exchange of experiences and planning of actions; with the aim to foster the modification of the health care model, for a model that cover since the health promotion to the rehabilitation of the population diseases..$^{18}$ The carrying out of collective activities is still considered a challenge for all the health professionals, whom still have, in their training, the centrality in the carrying out of technical procedures, individualized and tied to hard technologies.

Another factor that could make it difficult to carry out the visits is the distance between the health service and the covered area. It is common the teams be responsible for a cover area relatively distant from the health facility; it happens because in a same primary health care unit there is more than one team allocated, and there are numerous families to be visited, and thus, prioritize those with most need for home care. ${ }^{20}$ As was said before, due to geographical particularities of the interior of the state, there is need for the management to make available the transportation for the people locomotion until domicile. Data from the PMAQ second cycle show that of the health teams that met special populations, such as rural population, riverine or indigenous, only $55.4 \%$ made available means of transport up to home, added to that the lack of human and material resources for the teams. ${ }^{5}$

By means of this analysis, it was also seen that Manaus, the capital is among the 10 municipalities with the lowest ratio of home visit, concomitant to the lowest rates of FHS coverage in the trienniums analyzed. The low coverage added to the demand for productivity and influence area of unit higher than the coverage area collaborated to the work overload of the professionals. Due to these factors, many nurses opt for intramural activities in contrast to the home visits. It may also be that professionals limit the extramural actions, mainly by fear of urban violence, common situation in many locations where the health units are situated, being referred this type of violence to as territorial violence. ${ }^{21}$

In the last years, especially from 2003, there was a great expansion of FHS over all the national territory, with strong induction and support of the Ministry of Health, mainly because it is considered priority strategy of the structuring of the PHC in Brazil. ${ }^{22}$ In this context, studies show that the expansion in the coverage by the FHS is associated with the reduction of hospitalizations for diseases sensitive to primary health care, in practically all the Brazilian states, except in the Amazonas, where there was an increase of $30 \%$ on rates of hospitalizations from 1999 to $2007 . .^{5}$

During the study period (2010 - 2015), the Amazonas showed reduction of $30 \%$ in the number of hospitalizations for selected diseases sensitive to primary health care and increase in the FHS coverage with $80 \%$ of municipalities with classification of high coverage in the second triennium. However, the home visits by the nurse did not follow the increase of the FHS coverage, indicating that this increasing did not result in the reorganization of health care practices, which are able to intervene in the determinants of the health-sickness process.

The deficit in the quantitative of visits makes it difficult to identify all the families' needs, which represents a problem for the community health care. It can see that the lack of visits is a health care gap whose opportunity should be used for health promotion and the consequent diseases' prevention, which maybe could impact on the hospitalizations, although it is recognized that the problem of the hospitalization for conditions sensitive to PHC is much broader, and is influenced by other factors, such as: socioeconomic and demographic indicators, provision of health services, support network to PHC and professionals available (physicians/nurses). ${ }^{22,23}$ 


\section{CONCLUSION AND IMPLICATIONS FOR PRACTICES}

A paradox in the findings of this research is that even with high FHS coverage, in most of the municipalities of Amazonas, home visits are still not the main focus of nurses, since only $30 \%$ of the municipalities obtained one or more home visits per family recorded in both three-year periods. Home visits should be used as a tool for disease prevention and health promotion, which may explain the non-reduction of hospitalizations for sensitive conditions to primary care.

\section{REFERENCES}

1. Ministério da Saúde (Brasil). Portaria № 2.436, de 21 de setembro de 2017. Aprova a Política Nacional de Atenção Básica, estabelecendo a revisão de diretrizes para a organização da Atenção Básica, no âmbito do Sistema Único de Saúde (SUS). Brasília (DF): Diário Oficial da União; 2017. 68p. [cited 2017 Oct 25]. Available from: http://www. imprensanacional.gov.br/materia/-/asset_publisher/Kujrw0TZC2Mb/ content/id/19308123/do1-2017-09-22-portaria-n-2-436-de-21-desetembro-de-2017-19308031

2. Starfield B. Atenção primária: equilíbrio entre necessidades de saúde, serviços e tecnologia. Brasília (DF): UNESCO, Ministério da Saúde; 2002. 726 p. [cited 2017 Oct 25]. Available from: https://www.nescon. medicina.ufmg.br/biblioteca/imagem/0253.pdf

3. Kebian LVA, Acioli S. A visita domiciliar de enfermeiros e agentes comunitários de saúde da Estratégia Saúde da Família. Rev Eletr Enferm [Internet]. 2014 Jan/Mar; [cited 2018 Sep 29]; 16(1):161-9. Available from: http://dx.doi.org/10.5216/ree.v16i1.20260. DOI: 10.5216/ree.v16i1.20260

4. Motta LCS, Siqueira-Batista R. Estratégia Saúde da Família: Clínica e Crítica. Rev Bras Educ Méd [Internet]. 2015 Apr/Jun; [cited 2018 Jul 23]; 39(2):196-207. Available from: http://www.scielo.br/scielo. php?script=sci_arttext $\&$ pid=S0100-55022015000200196. DOI: 10.1590/1981-52712015v39n2e00912014

5. Oliveira HM, Gonçalves MJF, Pires ROM. Caracterização da estratégia saúde da família no estado do Amazonas, Brasil: análise da implantação e impacto. Cad Saúde Pública [Internet]. 2011 Jan; [cited 2015 Oct 14]; 27(1):35-45. Available from: http://www.scielo.br/ scielo.php?script=sci_arttext\&pid=S0102-311X2011000100004. DOI: 10.1590/S0102-311X2011000100004

6. Pinto Junior EP, Aquino R, Medina MG, Silva MGC. Efeito da Estratégia Saúde da Família nas internações por condições sensíveis à atenção primária em menores de um ano na Bahia, Brasil. Cad Saúde Pública [Internet]. 2018; [cited 2018 Oct 18]; 34(2):e00133816. Available from: https://www.scielosp.org/article/ssm/content/raw/?resource_ssm_ path=/media/assets/csp/v34n2/1678-4464-csp-34-02-e00133816. pdf. DOI: 10.1590/0102-311X00133816

7. Ferreira JBB, Borges MJG, Santos LL, Forster AC. Internações por condições sensíveis à atenção primária à saúde em uma região de saúde paulista, 2008 a 2010. Epidemiol Serv Saúde [Internet]. 2014 Jan/Mar; [cited 2018 Apr 2]; 23(1):45-56. Available from: http:// scielo.iec.gov.br/pdf/ess/v23n1/v23n1a05.pdf. DOI: 10.5123/S167949742014000100005

8. Henrique F, Calvo MCM. Avaliação do Programa Saúde da Família nos municípios do Estado de Santa Catarina, Brasil. Cad Saúde Pública [Internet]. 2008 Apr; [cited 2016 Sep 26]; 24(4):809-19. Available from: https://www.scielosp.org/article/ssm/content/raw/?resource ssm_path=/media/assets/csp/v24n4/11.pdf. DOI: 10.1590/S0102311X2008000400011
9. Classificação Internacional de Atenção Primária - CIAP-2. In: Gusso GD, ed. Florianópolis: Sociedade Brasileira de Medicina de Família e Comunidade; 2009. [cited 2016 Jan 20]. Available from: http://dms. ufpel.edu.br/ares/bitstream/handle/123456789/28/CIAP\%202\%20 -\%20WONCA\%20-\%20Livro.pdf?sequence=2

10. Organização Mundial da Saúde. Classificação estatística internacional de doenças e problemas relacionados à saúde. 10ª revisão. São Paulo: Centro Colaborador da Organização Mundial da Saúde para a Classificação de Doenças em Português; 1995.

11. Instituto para o Desenvolvimento da Saúde. Universidade de São Paulo. Ministério da Saúde (BR). Manual de Enfermagem. São Paulo (SP): Universidade de São Paulo. 2001. [cited 2017 Aug 16]. Available from: https://edisciplinas.usp.br/pluginfile.php/392602/ mod_resource/content/1/Fundamentos\%20e\%20cuidado\%20da\%20 enfermagem\%20na\%20sa\%C3\%BAde\%20da\%20fam\%C3\%ADlia. pdf

12. Freitas MAT. A Atuação do Serviço Nacional de Bioestatística nas Esferas Estatística e Sanitária. Rev Bras Estat [Internet]. 1943; [cited 2018 Apr 4]; 4(14):231-4. Available from: https://biblioteca.ibge.gov.br/ visualizacao/periodicos/111/rbe_1943_v4_n14.pdf

13. Gaíva MAM, Siqueira VCA. A prática da visita domiciliária pelos profissionais da Estratégia Saúde da Família. Ciênc Cuid Saúde [Internet]. 2011; [cited 2016 Sep 26]; 10(4):697-704. Available from: http://periodicos.uem.br/ojs/index.php/CiencCuidSaude/article/ view/18313. DOI: 10.4025/cienccuidsaude.v10i4.18313

14. Malta DC, Santos MAS, Stopa RS, Vieira JEB, Melo EA, Reis AA. A Cobertura da Estratégia Saúde da Família (ESF) no Brasil, segundo a Pesquisa Nacional de Saúde, 2013. Ciênc Saúde Coletiva [Internet]. 2016; [cited 2018 Jul 24]; 21(2):327-38. Available from: http://www. scielo.br/pdf/csc/v21n2/1413-8123-csc-21-02-0327.pdf. DOI: 10.1590/1413-81232015212.23602015

15. Gomes MFP, Fracolli LA, Machado BC. Atenção domiciliar do enfermeiro na estratégia saúde na família. Mundo Saúde [Internet]. 2015; [cited 2018 Jul 24]; 39(4):470-5. Available from: http:// www.saocamilo-sp.br/pdf/mundo_saude/155572/A08.pdf. DOI: 10.15343/0104-7809.20153904470475

16. Marcolino JS, Scochi MJ. Informação em saúde: o uso do SIAB pelos profissionais das Equipes de Saúde da Família. Rev Gaúcha Enferm [Internet]. 2010 Jun; [cited 2018 Apr 8]; 31(2):314-20. Available from: http://www.scielo.br/pdf/rgenf/v31n2/16.pdf. DOI: 10.1590/S198314472010000200016

17. Cunha MS, Sá MC. A visita domiciliar na estratégia de saúde da família: os desafios de se mover no território. Interface (Botucatu) [Internet]. 2013 Jan/Mar; [cited 2015 Mar 5]; 17(44):61-73. Available from: http://www.scielo.br/scielo.php?script=sci_art text\&pid=S1414-32832013000100006. DOI: 10.1590/S141432832013000100006

18. Ministério da Saúde (BR). Guia prático do Programa Saúde da Família Brasília (DF): Ministério da Saúde;2001. [cited 2017 Aug 16]. Available from: http://bvsms.saude.gov.br/bvs/publicacoes/partes/guia_psf1.pdf

19. Garnelo L, Lucas ACS, Parente RCP, Rocha ECR, Gonçalves MJF. Organização do cuidado às condições crônicas por equipes de Saúde da Família na Amazônia. Saúde Debate [Internet]. 2014 Oct; [cited 2018 May 21]; 38(n.spe):158-72. Available from: http://www.scielo.br/pdf/ sdeb/v38nspe/0103-1104-sdeb-38-spe-0158.pdf. DOI: 10.5935/01031104.2014S012

20. Santos AF, Fonseca Sobrinho D, Araujo LL, Procópio CSD, Lopes EAS, Lima AMLD, et al. Incorporação de Tecnologias de Informação e Comunicação e qualidade na atenção básica em saúde no Brasil. Cad Saúde Pública [Internet]. 2017; [cited 2017 Oct 2]; 33(5):e00172815. Available from: http://www.scielo.br/pdf/csp/v33n5/1678-4464-csp-3305-e00172815.pdf. DOI: 10.1590/0102-311x00172815 
21. Polaro SHI, Gonçalves LHT, Alvarez AM. Enfermeiras desafiando a violência no âmbito de atuação da Estratégia de Saúde da Família. Texto Contexto Enferm [Internet]. 2013 Oct/Dec; [cited 2018 Jul 24]; 22(4):935-42. Available from: http://www.scielo.br/pdf/tce/v22n4/09. pdf. DOI: 10.1590/S0104-07072013000400009

22. Lopes $\mathrm{MCL}$, Marcon SS. Assistência à família na atenção básica: facilidades e dificuldades enfrentadas pelos profissionais da saúde. Acta Sci [Internet]. 2012 Jan/Jun; [cited 2018 Apr 8]; 34(1):85-93. Available from: http://docs.bvsalud.org/biblioref/2016/08/1311/7624-61172-1-pb. pdf. DOI: 10.4025/actascihealthsci.v34i1.7624.
23. Castro ALB, Andrade CLT, Machado CV, Lima LD. Condições socioeconômicas, oferta de médicos e internações por condições sensíveis à atenção primária em grandes municípios do Brasil. Cad Saúde Pública [Internet]. 2015 Nov; [cited 2018 May 31]; 31(11):235366. Available from: http://www.scielo.br/pdf/csp/v31n11/0102-311Xcsp-31-11-2353.pdf. DOI: 10.1590/0102-311X00126114.

a Source of data: Brazilian Institute of Geography and Statistics. @cidades [homepage]. Data from the State of Amazonas. Available at: https://cidades.ibge. gov.br/brasil/am/panorama. Access in 11/28/2018 